litigation is not to find the most expeditious method of deciding a private controversy which the court alone has power to decide, but rather to select procedural rules which will do most to preserve a statesmanlike balance between the three co-ordinate departments of American government; to avoid encroachment which would nullify the powers of one or the other, or excessive friction which would threaten the entire machinery. Easy, simple access to the courts in private litigation is a matter of economy, convenience and justice in judicial administration. Access to the courts in constitutional litigation is a matter of politics in its higher sense, and in their view ease and speed may be the surest way of destroying the very institution of judicial review.

At least in the absence of such direct limitations on the scope of judicial review as might be interposed by statute ${ }^{70}$ or constitutional amendment, a discreet use of empty formulae like the idea of irreparable injury can materially support a policy of judicial self-restraint.

\title{
OPTIONS AND SALE CONTRACTS IN TAXATION
}

PROPERTY is not always transferred instantaneously. Rather, the rights, powers, privileges, etc., constituting the "property" are often transferred in groups passing at successive stages in the transaction. For example, $A$ may give $B \propto$ an option to purchase certain property, thus conferring on $B$ the power to create in $A$ the duty to convey the property. If $B$ then exercises his option, a contract of sale is made which is said to give $B$ equitable title with its legal implications. Finally, legal title and any remaining rights, privileges, etc., may pass at some still later date. During this period of transfer there is, in a sense, a split in ownership. Yet tax statutes are generally written in terms of the simple property concepts of individual ownership and instantaneous acquisition. Difficulties are therefore inevitable in determining how these simple terms should be interpreted when applied to property in the process of transfer. The problems are primarily of two types, the first concerning death taxes, and the second, income taxes.

\section{Death TAXES}

When property is in the process of transfer from the decedent at the time of his death, two types of difficulties may arise: that of determining whether the decedent's interest is within the taxing jurisdiction and that of determining the value of the taxable estate.

70. See Haines, Judicial Revieze of Acts of Congress and the Need for Constitn-

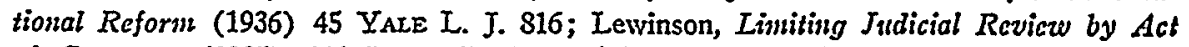
of Congress (1935) $23^{\circ}$ CaIIF. I. Rev. 591; Comment (1936) 4 Geo. Wast. I. REV. 381. 
Jurisdiction: When a man dies, his tangible property is subject to death taxes by the state in which it is located, ${ }^{1}$ but his intangible property is taxable only by the domiciliary state of the decedent. ${ }^{2}$ Land is admittedly tangible property. But where land is subject to a sale contract, the vendor's interest is generally considered in property law as intangible personalty under the socalled doctrine of equitable conversion. ${ }^{3}$ Accordingly, when a decedent owned foreign land subject to a sale contract at the time of his death, the problem has frequently arisen as to whether his interest was tangible, and hence taxable at the situs of the realty, or intangible, and therefore taxable by the domiciliary state. Several states have utilized the equitable conversion concept and heid that the land is to be treated as intangible personalty. But a minority of states consider the land as realty, and hence taxable only at the situs, on the ground that conversion is a fiction in the law of real property which should not be used to confuse taxation. ${ }^{.}$If, as a consequence of this split, the state of situs of the realty and the state of domicile of the decedent have different rules, the same property may be taxed twice, or not at all.c

1. Frick v. Pennsylvania, 268 U.S. 473 (1925).

2. Farmers' Ioan and Trust Co. v. MIinnesota, 280 U. S. 204 (1930).

3. Stone, Equitable Contversion by Contract (1913) 13 CoL L. REv. 369; Simpson, Legislative Changes in the Law of Equitable Conzersion by Contract (1935) 44 Yare I. J. 559, 754.

4. Either the domiciliary state claims conversion so as to tax land at the domicile, State ex rel. Filton v. Probate Court of Ramsey County, 145 Minn. 155, 176 N. W. 493 (1920), or the estate can claim conversion so as to defeat a tax by the state of situs, Iir re Boshart's Estate, 107 Mlisc 697, 177 N. Y. Supp. 567 (Surr. Ct. 1919), aff'd, 188 App. Div. 788, 177 N. Y. Supp. 574 (4th Dep't, 1919); In re Eilermann's - Estate, 179 Wash. 15, 35 P. (2d) 763 (1934).

No cases have been discovered involving the tasation of a decedent vendee's interest in foreign land. Logically, those states which consider the vendor's interest as converted into personalty should treat the vendee's interest as realty. Cf. Bartlett v. Gill, 221 Fed. 476 (D. Mass. 1915). In that event, only the state where the land is situated could tax. The question might then arise as to whether the purchase price should ba a deductible debt at the domicile. However, such a deduction would not seem proper by analogy to the denial of the deductibility of a mortgage debt on foreign land. U. S. Treas. Reg., 362 C.C.H. (1936) Fed. Tax Serv. 12075; see State ct rcl. Hilton v. Probate Court of Ramsey County, 145 Minn. 155, 15S, 176 N. W. 493, 494 (1920). If the vendee's interest is considered to be personalty, it should be tized like any other contract right. The scarcity of cases on this point may be partis due to the fact that taxation of the vendee's interest by the state of situs on the theory of conversion would be impractical, since the state would have no sure method of discovering the death of a prospective purchaser.

5. In re Baker's Estate, 67 Misc. 360, 124 N. Y.Supp. 827 (Surr. Ct. 1910); In re Wolcott's Estate, 94 Misc. 73, 157 N.Y. Supp. 26S (Surr. Ct. 1916); In re Paul's Estate, $303 \mathrm{~Pa} .330,154$ Atl. 503 (1931); cert. denied, 284 U.S. 630 (1931), (1931) 41 YaLE I. J. 140.

6. In State ex rel. Hilton v. Probate Court of Ramsey County, 145 Minin. 155, 176 N.W. 493 (1920), the court, in permitting Minnesota to tax; considered it immaterial that MIontana had already taxed the property. 
Either result would be unfair, and double taxation might even be considered unconstitutional, in view of the recent Supreme Court cases forbidding that practice. ${ }^{7}$ A simple adjustment of the difficulty could be achieved by the unanimous adoption of one rule or the other, the choice being relatively unimportant, but such a solution would encounter the barrier of established and conflicting authority. A more practical method would seem to be for both states in each case to use the rule of the jurisdiction in which the land is situated. This conflicts rule has been applied in a few tax cases involving equitable conversion by will or under the terms of a trust, ${ }^{8}$ and it is generally used in cases concerning the devolution of property where the domiciliary state and the state of situs disagree on whether an interest in land is realty or personalty. ${ }^{0}$ If this rule were adopted, one and only one state could tax regardless of the conflict between the states as to which rule is correct.

Valkation: The chief difficulty in the valuation of a decedent's property which is subject to an option or a sale contract lies in the fact that valuation must be based solely on factors existing at the time of death, ${ }^{10}$ whereas the final transfer under the contract takes place, if ever, at some later date. The value of the property at the time of death is concededly limited to some extent by the restrictive effect of such a contract. Litigation develops when the decedent's estate claims that the contract is not merely a factor in valuation, but rather a conclusive ground for limiting valuation to the contract price.

The simplest situation arises when property of the decedent is subject to an executory sale contract. In such a case it seems to have been assumed that the decedent's interest may not be valued above the sale price. ${ }^{11} \mathrm{~A}$ similar problem is presented when property is subject to an irrevocable option. The optionee can then create in the estate a duty to transfer the property even though the estate can not compel him to purchase. Hence, under normal business conditions the value of the property to the estate will rarely exceed the option price, for if the property is worth more, the optionee will usually exercise his option; and the estate will be allowed to

7. Farmers' Loan and Trust Co. v. Minnesota, 280 U. S. 204 (1930); First National Bank of Boston v. Maine, 284 U. S. 312 (1932).

8. Bates v. Decree of Judge of Probate, 131 Me. 176, 160 Atl. 22 (1932); Land Title and Trust Co. v. South Carolina Tax Comm., 131 S. C. 192, 126 S. E. 189 (1925).

9. Clarke v. Clarke, 178 U.S. 186 (1900); In re Berchtold, [1923] 1. Ch. 192; Re Burke, [1928] 1 D.L.R. 318 (Saskatchewan); see RestatenEnt, Confrict of Laws (1934), $\$ \S 208,209,244$. But see (1928) 41 Harv. L. Rev. 795.

10. Hooper v. Bradford, 178 Mass. 95, 59 N.E. 678 (1901); Iit re Penfold's Estate, 216 N.Y. 163, 110 N.E. 497 (1915). Under the 1935 Revenue Act, the executor may elect to value the estate as of one year after the date of death. 49 STAT. 1022, 26 U.S. C. A. $\$ 411$ (j) (Supp. 1935).

11. Valuation depends primarily upon the value of the purchaser's promise to pay, the property entering only as additional security. Hiram S. Norton et al., 16 B.T.A. 1115 (1929). 
retain the property only if it is worth less than the option price. There is therefore sound practical justification for holding that where property is at death subject to an option, the property may not be valued above the option price. But the option may not be exercised even though the property is admittedly worth more than the option price. That situation was presented in Wilson $v$. Bowers, ${ }^{12}$ where it was held that since valuation must be based solely on factors existing at the time of death, the subsequent failure to exercise the option is immaterial, and valuation cannot exceed the option price.13

A slightly different problem is presented when the contract gives the purchaser merely a so-called prior refusal. Thus the stockholders of a corporation frequently agree that no one of them may sell his stock without first offering it to the others at a price fixed, or to be determined in a certain manner. If Such an agreement generally is not worded to prevent the bequest of the stock. ${ }^{15}$ Suppose then that a stockholder dies, leaving the stock to $X$. Suppose further that the agreed price is $\$ 100$ a share, but that the stock has been paying annual dividends of $\$ 25$ a share. Although the stock cannot be sold for more than $\$ 100$ a share, it was probably worth far more than that to the decedent, and will be worth more to $X$, because of the dividend rate. Fence in several Board of Tax Appeals cases the government was, under such circumstances, allowed to value stock above the agreed price, although the restriction was recognized as a factor lowering the value of the stock. ${ }^{10}$ However, in a recent circuit court of appeals case it was held that since the stock could not be sold for more than the agreed price, it could not be valued at more. ${ }^{17}$ Yet it seems erroneous thus to treat selling price as conclusive when, in fact, a duty to sell cannot be imposed.

12. 57 F. (2d) 682 (C.C.A. 2d, 1932), aff'g 51 F. (2d) 261 (S.D.N.Y. 1931).

13. The opposite result had been reached in an earlier Board of Tax Apprals case, U. I. Kaufman, 5 B.T.A. 31 (1926), which was, however, not mentioned in the Wilson case.

14. As for the validity of such a contract, see Lomb v. Sugden, S2 F. (2d) 166 (C. C. A. 2d, 1936); Scruggs v. Cotterill, 67 App. Div. 583, 73 N. Y. Supp. SS2 (1st Dep't 1902).

15. If the agreement prevented the bequest of the stock, it would seem that since the estate could be compelled to sell the stock, the restriction would be as effective as an outright option to purchase at death, and therefore analogous to Wilson $v$. Bowers, sipra note 12. However, this problem does not seem to have been squarely raised as yet. Cf. Lomb v. Sugden, 11 F. Supp. 472 (W.D.N.Y. 1935), rej'd, \&2 F. (2d) 166 (C. C.A. 2d, 1936); The Attorney General v. Jameson, [1905] 2 I. R. 218; Waldemar R. Helmholz, Ex'r, 28 B.T.A. 165 (1933) semble.

16. City Bank Farmers Trust Co., 23 B.T.A. 663 (1931); The Mlichigan Trust Co., 27 B.T. A. 556 (1933); Frederick A. Koch, Jr., 28 B.T.A. 363 (1933); Estate of Louise N. Schulz, 14 B.T.A. 419 (192S) samble.

17. Iomb v. Sugden, S2 F. (2d) 166 (C. C. A. 2d, 1936), rov'g 11 F. Supp. 472 (W.D.N.Y. 1935). For a similar English case, see In rc Paulin, Deceased, [1934] W.N. 173, criticized in 178 L. T. 83 (1934). Contra: The Attorney General v. Jameson, [1905] 2 I.R. 218; Smyth v. Revenue Commissioners, [1931] I. R. 643. 
While the foregoing rules of valuation are necessary to prevent overvaluation of the decedent's interest, they would, if unsupplemented, open the door to evasion. For example, suppose a testator wishes to bequeath certain property to $A$. The testator can achieve almost the same result by giving $A$ an option to purchase the property after the testator's death for a nominal sum, or by making a sale contract with $A$ on similar terms, and under the foregoing rules of valuation, the decedent's interest at the time of death could not be valued above the nominal agreed price. Hence, in order to round out the scheme of death taxation, it was found necessary to include in the gross taxable estate not only the decedent's interest in the property, but also, in certain cases, the purchaser's. This was achieved under the statutory provisions which include in the taxable estate transfers to take effect at or after death. ${ }^{18}$ The interpretation of these provisions can probably best be understood by an historical survey of the experience under the New York statute. ${ }^{19}$

The original New York statute ${ }^{20}$ provided for the taxation of all transfers taking effect at or after death. This broad provision threatened to include contracts performed after death resulting from bona fide business transactions. It was therefore held at an early date that the statute did not include transfers for consideration. ${ }^{21}$ But then a case arose in which two brothers made mutual promises that the survivor should have an option to purchase certain of the decedent's stock for $\$ 60$ a share. Clearly the estate of the first to die was taxable for the stock at $\$ 60$ a share. However, the stock was actually worth far more, and the state therefore tried to tax as a transfer to take effect at or after death the difference between the actual value and the $\$ 60$ a share already included in the taxable estate. The tax was allowed, ${ }^{22}$

18. The present federal statute which is typical of these provisions reads: "The value of the gross estate of the decedent shall be determined by including the value at the time of his death of all property. ... .

(a) To the extent of the interest therein of the decedent at the time of his death;

(c) To the extent of any interest therein of which the decedent has . . . made a transfer . . . intended to take effect ... at or after his death ... except in case of a bona fide sale for an adequate and full consideration in money "or money's worth." 44 STAT. 70 (1926), 26 U.S. C. \$411 (1934).

19. For a thorough analysis of this development, see Matter of Howell, 255 N. Y. 211, 174 N.E. 457 .(1931).

20. N. Y. Laws of 1896, Ch. $908, \S 220(3)$, as amended by Laws of 1897, Ch. 284.

21. Matter of Miller, 77 App. Div. 473, 78 N.Y. Supp. 930 (2d Dep't 1902); Matter of Baker, 83 App. Div. 530, 82 N. Y. Supp. 390 (4th Dep't 1903), aff'd without opinion, 178 N.Y. 575,70 N.E. 1094 (1904).

22. Matter of Cory, 177 App. Div. 871, 164 N.Y. Supp. 956 (1st Dep't 1917), aff'd wittont opinion, 221 N.Y. 612, 117 N.E. 1065 (1917). The transfer is included in the taxable estate only to the amount of the difference between market value and $\$ 60$ a share because $\$ 60$ a share is already included as the value of the decedent's interest. The present federal and New York statutes [44 STAT. 71-72 (1926), 26 U.S. C. $\$ 411$ (i) (1934); N.Y. TAX LAW (1930) \$249r (11)] specifically provide that such transfers are taxable only as to the difference between market value and 
and the rule developed that whereas transfers for consideration are generally exempt, this exemption does not apply where the transfer is primarily donative and testamentary in nature. ${ }^{23}$ This test is now generally used in other courts also, ${ }^{24}$ but it has caused frequent litigation as to when a transfer for consideration is primarily donative. In analyzing the cases, it should be noticed that the term donative may have two meanings. It may refer to the intent of the decedent to make a gift, in which case the issue should hinge on his intent at the time the contract was made. On the other hand, "donative" may mean the actual giving of something, and the issue should then depend upon whether the agreed price is as high as the market value of the property at the time of death. Since the purpose of the statute is not to tax business transactions in which the transferor got a bargain, but rather transfers of a testamentary nature, it would seem that "donative" should be held to refer to intent. ${ }^{25}$ But this definition can hardly be kept clear-cut, for a large discrepancy between market value and the agreed price at the time of death may be treated as evidence that the decedent intended to make a gift when he entered into the contract. And the definition becomes particularly difficult to apply in the following type of situation when the motives for the transaction may be beneficent, commercial, or both.

If the members of a small firm. desire to continue their business after the death of any of their number, they are likely to encounter serious difficulties. For if the firm is incorporated, the stock of the decedent passes to his estate, and the remaining stockholders may have difficulty in purchasing the stock

the value of the consideration given. It is interesting to note, however, that for this purpose a promise in an aleatory contract which need not be performed is not treated as consideration. See Int re Huggins Estate, 96 N. J. Eq. 275, 282, 125 Atl. 27, 29 (Prerog. Ct. 1924).

23. In qe Orvis' Estate, 223 N.Y. 1, 119 N.E. SS (1918), afj'g 179 App. Div. 1, 166 N. Y. Supp. 126 (1st Dep't 1917). But cf. Int re Fieux's Estate, 241 N.Y. 277, 149 N.E. 857 (1925) (here the stockholders of a small corporation agreed that if any one of them retired from the firm or died, the others were to buy his stock The agreement was held not primarily testamentary). The New York statute [N.Y. TAx LAW (1930) $\$ 249 \mathrm{r}(3)]$ has since been amended to conform with the federal statute, see sipra note 18, but this would seem to be intended as merely declaratory of the prior law.

24. Safe Deposit and Trust Co. v. Tait, 295 Fed. 429 (D. Md. 1923); Phillips v. Gnichtel, 27 F. (2d) 662 (C. C.A. 3d, 1928); In re Huggins Estate, 96 N. J. Eq. 275,125 Atl. 27 (Prerog. Ct. 1924); cf. Will of Jones, 206 Wis. 4S2, 240 N. W. 186 (1932). But of. Rose Newman, 31 B.T.A. 772 (1934); Davidson v. Rafferty, 34 F. (2d) 700 (E. D. N. Y. 1929).

25. No case has been found in which a transfer pursuant to an admittedly business transaction was taxed simply because the purchaser drove a good bargain, but under the present wording of the federal and New York statutes [43 STsт. 304 (1924), 26 U.S.C. $\$ 411$ (1934); N. Y. TAX LAW (1930) $\$ 249 \mathrm{r}(3)]$ taing all transfers taking effect at death unless by a bona fide sale for fair and adequate consideration, it could be argued that even if there was no donative intent, if the purchaser Eave so little consideration as to be inadequate, the transfer might be tarable. 
from the estate. On the other hand, if the firm is a partnership, it is automatically dissolved on the death of any member, and the estate of the decedent is entitled to the value of the decedent's share in the partnership. But frequently the valuation of this interest causes a dispute that requires the time and expense of judicial settlement. To avoid these difficulties, the members of such firms often agree that the interest of any decedent shall be purchased by the survivors at a figure to be calculated according to some agreed method of valuation. Under the rules of valuation previously considered, such an agreement limits the taxable value of the decedent's interest to the contract price. However, the members of a small firm may wish to leave something at death to their business associates. Therefore, in making such an agreement, they may select a method of valuation resulting in an at least conservatively low estimate of the firm's worth. For example, they frequently agree to take book value without any addition for good will. Hence when the valuation under such an agreement seems distinctly low, the tax officials may assert that the transfer is donative, and thus taxable on the difference between its actual worth, as found by a court, and the valuation under the agreement. The mere fact that at the time of death the tax officials disagree with the firm's valuation should not be sufficient grounds for taxation, since the justification for such a tax lies in the existence of a donative intent. But since positive proof of the parties' intent is usually lacking, the state courts seem to have accepted evidence to show that the agreed method of valuation is not the usual one. Thus, where the method of valuation is book value without addition for good will, the state cases hold that good will may be valued and taxed.90 Yet since good will is highly speculative, and since in the case of some firms it may be practically valueless, an agreement not to value good will does not seem donative per se. ${ }^{27}$ It would seem preferable not to lay down general rules, but rather to determine in each case whether the agreed method of valuation can be justified as realistic.

On the whole, the rules for taxing estates containing property subject to an option or executory contract are reasonably consistent and simple. With a few exceptions, the estate has been protected from taxation above the actual value to the beneficiaries of the property involved, and the possibilities of evasion have been to a large extent eliminated by the rule that when

26. In re Hall's Estate, 94 N. J. Eq. 398, 119 Atl. 669 (Prerog. Ct. 1923); In re Deutz's Estate, 105 N. J. Eq. 671, 149 Atl. 257 (Prerog. Ct. 1930); In re Burgheimer's Estate, 91 Misc. 468, 154 N. Y. Supp. 943 (Surr. Ct. 1915); In re Cohen's Estate, 170 N. Y. Supp. 156 (Surr. Ct. 1918); In re Halle's Estate, 103 Misc. 661, 170 N. Y. Supp. 898 (Surr. Ct. 1918); In re Hellman's Estate, 172 N. Y. Supp. 671 (Surr. Ct. 1918), aff'd, 174 N.Y. Supp. 905, aff'd, 226 N. Y. 702, 123 N. E. 869 (1919). Contra: In re Borden's Estate, 95 Misc. 443, 159 N. Y. Supp. 346 (Surr. Ct. 1916) (seemingly overruled by the New York cases, supra); William P. Blodget, 18 B.T. A. 1050 (1930).

27. Possibly the Board of Tax Appeals is aiming towards such a rule. Cf. William P. Blođget, 18 B.T.A. 1050 (1930). 
a contract is not part of a bona fide business transaction, the government may tax the property at its full value by taxing the decedent's interest at the contract price, and by taxing as a transfer to take effect at death the difference between the actual value of the property and the contract price. Yet Wilson $v$. Bowers seems to have left one loophole requiring consideration. Suppose $A$ gives $B$ an option to purchase certain stock for $\$ 10,000$, the option to be exercised within one month after $A$ 's death. When $A$ dies, according to Wilsonz $v$. Bowers, the stock may not be valued at above $\$ 10,000$, even if the option is not later exercised. Now suppose that the stock is worth $\$ 100,000$, and that the contract is admittedly donative. If $B$ exercises the option there will be a tax on $\$ 90,000$ as a transfer to take effect at death, and the whole $\$ 100,000$ will thus be taxed. But if $B$ fails to exercise the option, there would seem to be no basis for any estate tax other than on the original $\$ 10,000$. Hence if $W$ ilson v. Bowers is followed, an easy method of evasion is available, for $A$ could readily assure himself that the option would not be exercised by giving it to the legatee of the property under the will.

\section{Inconre Taxes}

In the death tax cases hitherto discussed, a fixed moment in the process of transfer was taken, the moment of death, and the difficulty lay in determining the status and value of the decedent's interest as of that point. In the income tax cases there arises the converse problem of determining the particular moment at which the transfer may be said to take place. This problem has two aspects, that of determining the moment at which the seller "parts" with the property, and that of selecting the moment at which the buyer "acquires" the property. Although these are only different sides of the same picture, there seems no logical necessity for using in all cases the same criteria for selecting the moment of transfer, since the concept of a single moment of transfer is so obviously a fiction. The problem may be subdivided according to the practical issues involved. First, it is necessary to select a point at which the transfer may be considered to have occurred, in order to decide the year in which the seller has realized his profit or loss. In the seeond place, an arbitrary choice must sometimes be made as to the moment at which the seller will be considered to have acquired the property originally, in order to decide which of several statutory provisions is applicable. And finally, both a moment of sale and an original moment of acquisition must be selected in order to ascertain how long the vendor has held the property, a fact which becomes relevant under the capital gains provision.

In What Year Is Incone Realized? Income taxes are collected annually. Hence when a taxpayer sells property at a gain or loss, it becomes necessary to fix a year within which he may be said to realize that gain or loss. The practical factors to be considered in selecting this point are, first, that the vendor should not be compelled to pay a tax on his profit until there is a reasonable certainty that it will actually be realized, and second, the govern- 
ment should be permitted to tax income as soon as possible in the interests of the public purse. The rule of the courts is often said to be that income is realized at the first moment at which there is created an "enforceable liability" for the purchase price, ${ }^{28}$ perhaps more accurately described as a "right" to the purchase price. An attempt will be made to determine the extent to which the decided cases can be thus easily classified.

Since the dominant characteristic of an option is that the optionee is not bound to purchase, under this rule, a prospective seller would appear to have realized no profit while his property is subject only to an option contract. But although the optionee may be under no legal compulsion, as a practical matter he may be forced to purchase. Thus in one case, where a four year lease with an option to purchase set an annual rental of roughly one-fourth the value of the property, and an option price of $\$ 1$, it was held that since, as a practical matter, the optionee had no choice but to buy, the contract, although in form an option, should be treated as a sale.20 But where there is an actual chance that the optionee may not buy, the courts will postpone taxation even though the chance is slight. ${ }^{30}$

Once an option has been exercised, or a contract of sale made, theoretically the vendor has a right to the purchase price, and his profit would be taxable at that point if the courts applied the test that income is realized when the vendor acquires a right to collect the purchase price. Yet if a sale contract provides that the purchaser may rescind and pay liquidated damages, the contract is fairly similar to an option. ${ }^{31}$ Hence the profit is not generally considered taxable until there has been further performance. ${ }^{32}$ Similarly, where a contract is largely executory, even though the purchaser is technically bound, there often remains a fair possibility that the contract will never be performed, or will be performed under altered terms. Therefore the courts have frequently postponed taxation until there has been sufficient performance to create a reasonable practical certainty that the contract will be carried out as agreed. ${ }^{33}$ Thus in the leading case of Lucas $v$. North Teras Lumber Company, 34 where the vendor gave an option on December 27, 1916,

28. Ohio Brass Co., 17 B.T.A. 1199, 1203 (1929). For further discussion and additional cases, see I Paur and MERtens, Federal Incone Taxation (1934) 11.47. Although reference to an enforceable liability suggests consideration of the remedy available to the vendor, the courts have not distinguished between cases in which the vendor could get the full purchase price and those in which he could get only damages.

29. A. B. Watson, 24 B. T. A. 466 (1931), aff'd, 62 F. (2d) 35 (C. C. A. 9th, 1932); cf. I. T. 1819, II-2 Cum. Bull. 73.

30. Arthur J. Coyle, 17 B. T. A. 368 (1929); cf. Chisholm v. Commissioner, 79 F. (2d) 14 (C.C.A. 2d, 1935); John T. Morris, 15 B.T.A. 260 (1929); The Grand Rapids Trust Co., 34 B.T. A., March 20, 1936.

31. Sheeby. v. Scott, 128 Iowa 551, 104 N. W. 1139 (1905).

32. Parish-Watson \& Co., Inc., 4 B.T. A. 605 (1926); Friend M. Aiken, 10 B. T. A. 553 (1928); Higgins Estate, 30 B. T. A. 814 (1934).

33. Newaygo Portland Cement Co., 27 B.T.A. 1097 (1933); Falls City Ice and Beverage Co., 27 B. T. A. 1346 (1933).

34. 281 U. S. 11 (1930), rev'g 30 F. (2d) 680 (C. C. A. 5th, 1929). 
which was exercised on December 30,1916, the actual conveyance, however, not taking place until January 5, 1917, the United States Supreme Court held that the vendor had not realized his profit until 1917.35

Considering these cases as a whole, it becomes clear that the "enforceable liability" test, while conceptually convenient, is not strictly adhered to; it has been necessary to make a practical compromise with the rule, and look to the actual rather than the legal effect of a contract. No general rule seems strong enough to support assured prediction, but the important factors which tend to be decisive in any individual case seem to be (1) the moment at which the purchaser gets possession, ${ }^{36}$ or if an intangible is involved, practical dominion, ${ }^{37}$ and (2) the amount of the consideration which has already been paid, ${ }^{38}$ and the definiteness as to time ${ }^{39}$ and amount ${ }^{30}$ of the consideration remaining to be paid.

When is Property Acquired? It sometimes becomes necessary to determine when property was acquired because, in taxing the profit from a sale, different statutory provisions may apply, depending upon the date at which the vendor originally acquired the property. For example, the tarable profit from a sale is generally calculated by deducting cost from sale price, but in order to avoid the taxation of gains actually accruing prior to Miarch 1, . 1913, the date of the Income Tax Amendment, it is provided that where

35. The Court attempted to justify its decision by interpreting "enforceable liability" for the purchase price as "unconditional liability" for the purchase price, and holding that since the deed was not tendered till 1917, the liability had not become unconditional until then. Yet a strict adherence to this rule would generally postpone tasation until the vendor had tendered complete performance, which is, for proctical tax purposes, often far too late in the transfer. Hence the lower courts, while following the North Texas case on its facts [see Falls City Ice \& Beverage Co., 27 B.T. A. 1346 (1933)], have ignored the attempt to prefix unconditional to "enforceable liability." Union Pacific R. R. Co., 32 B.T.A. 383 (1935); A. B. Watson, 24 B.T.A. 466 (1931), aff'd, 62 F. (2d) 35 (C. C.A. 9th, 1932).

36. Newaygo Portland Cement Co., 27 B.T. A. 1097 (1933) (contract for sale of land made in 1922, with $10 \%$ down payment, but vendor retaining possession till completion of payment in 1923 not taxable until 1923) ; A. B. Watson, 24 B.T.A. 466 (1931); Parish-Watson \& Co., Inc., 2 B. T. A. $\$ 51$ (1925); Union Pacific R. R. Co., 32 B.T.A. 383 (1935) (contract for sale of land made in 1920, with $25 \%$ of payment in 1920, but remaining payments spread till 1926. Purchaser took possession, hence taxable in 1920); Edwin M. Brown, I B. T. A. 502 (1925).

37. Brunton v. Commissioner, 42 F. (2d) 81 (C. C.A. 9th, 1930), cert. delicd, 282 U. S. $\$ 89$ (1930) (contract for sale of stock, made in 1921, "to be consummated in 1922," but held taxable in 1921 because seller gave buyer an irrevocable power of attorney for the stock).

38. Brunton v. Commissioner, 42 F. (2d) 81 (C.C.A. 9th, 1930) (payment not made until 1922, but the fact that the purchaser gave collateral to secure payment deemed a factor justifying taxation in 1921).

39. Teck Hobbs, 26 B.T.A. 241 (1932) (sale of oil lease for $\$ 300,000$ to be paid out of oil as produced, held so uncertain as to time of payment as not to be tasiable immediately).

40. Commissioner v. R. J. Darnell, Inc., 60 F. (2d) $\$ 2$ (C. C.A. 6th, 1932). 
property was acquired prior to that date, and the market value as of that date exceeded cost, then this market value shall be used instead of cost in computing the taxable profit. 41 The difficulty lies in determining how far the process of transfer must have progressed by March 1, 1913 in order that the purchaser may be said to have acquired the property. ${ }^{22}$ In one case where a sale contract was made prior to 1913 , but conveyance and part of the payment did not take place till later, it was held that the equitable title created by the contract was sufficient acquisition. ${ }^{43}$ But that anything less could be considered acquisition would seem doubtful after the recent Supreme Court decision in Helvering v. San Joaquin Frut and Investment Company, 4 which held that ownership on March 1, 1913, of a lease to property with an option to purchase did not constitute acquisition even though the option price was so far below the value of the property that as a practical matter the optionee was sure to purchase. ${ }^{45}$ This decision would seem to indicate that strict conveyancers' rules will be used in defining acquisition, rather than the more flexible tests employed in determining the moment of sale. This distinction

41. 48 Stat. 708 (1934), 26 U.S.C. (1934) §113(a) 14. This problem could also arise under subdivisions 7,8 , and 12 of the above code provision.

42. For related cases arising under this statute, see Heiner v. Hewes, $30 \mathrm{~F}$. (2d) 787 (C. C. A. 3d, 1929) (In 1913, taxpayer was litigating over title to land, and suit was later settled in his favor. Held, that he had good title throughout, and hence acquired property prior to 1913); City Bank Company, 1 B.T.A. 210 (1924) (Taxpayer bid for property in receivership on February 28, 1913, and bid was accepted on March 24. Held, that although taxpayer was bqund by offer, vendor was not, and there was therefore no acquisition prior to March 24); Commercial Truck Company of America, 5 B.T.A. 602 (1926); N. G. Behles, 30 B.T. A. 1208 (1934).

43. Arthur B. Grover, 3 B. T. A. 508 (1926).

44. 56 S. Ct. 569 (1936). Followed in Helen E. Leatherbee \& State Street Trust Company, 34 B.T.A., March 24, 1936.

45. Since in the San Joaquin case the option price was $\$ 200,000$, while the admitted value of the property was $\$ 1,000,000$ on March 1,1913 , the use of cost, or $\$ 200,000$, in computing profit resulted in taxing $\$ 800,000$ which was actually attributable to an increase in the value of the land occurring prior to 1913. The Supreme Court disposed of the argument that such a retroactive application of the Amendment would be unconstitutional by stating that while the profit accrued to the land prior to 1913, this profit could not accrue to the taxpayer until he actually acquired the land, which, according to the Court, did not take place till the option was exercised in 1916. This is a somewhat unconvincing distinction, since the -taxpayer by his ownership of the option was in a position before 1913 to benefit by the increase in value, his option itself having become worth roughly $\$ 800,000$ because of the increase in property value. Belridge Oil Co. v. Commissioner, 364 C. C. H. 1936 Fed. Tax Serv. $\llbracket 9473$ (C. C. A. 9th, 1936). However, in determining whether a tax is unconstitutional as reaching profit accruing during an exempt period, the courts have tended when possible to uphold taxation even if on technical grounds. Lynch v. Hornby, 247 U.S. 339 (1918) (Stockholders taxed for dividends received after 1913 out of profits earned before 1913); Grace W. Dick, 30 B.T.A. 1304 (1934) (Profit accruing to Indian land while exempt from property taxation was subject to income taxation where sale occurred after the exemption was lifted). 
may be functionally justified, for a strict rule is more convenient in cases involving the arbitraty determination of which of two statutory provisions shall apply, whereas, for the practical and administrative reasons discussed above, a more flexible rule is preferable in determining when income is realized.

How Long Has Property Beent Held? Capital gains are profits derived from the sale of long held assets. Such profits ordinarily accrue over the whole period of ownership, yet the profit must generally be taken in one year. Hence a capital gain might throw the taxpayer's income into the higher surtax brackets. This danger would so seriously discourage the sale of long held assets that it was found necessary to lessen this burden. The earlier revenue acts ${ }^{46}$ provided that in case of profits from the sale of assets other than stock in trade which had been held for over two years, the taxpayer had the choice of paying the normal graduated rate or a flat $12 \% / 2 \%$ rate. Under the new revenue act, ${ }^{4 \tau}$ capital gains are grouped with normal gains, but only a certain percentage of the profit is taxable, decreasing according to the length of time the asset has been held. Further, there are now five classifications, depending upon the length of holding, with different rates for each class. ${ }^{48}$ Hence the problem of determining the exact holding period will be of increased importance in the future.

The end of the holding period is the moment when income is said to be realized as determined by the criteria already discussed.10 In general, the period is considered to begin at the single point, hitherto defined, when the property is "acquired". 50 But in some cases, appreciable amounts of money are invested at widely separated times, either before or after the single moment of acquisition which would thus be selected. Since one of the purposes of the present act is to make the tax proportional to the length of time capital has been invested, there is strong practical justification for dividing the profit into parts which can be attributed to each of these investments and taxing each part according to the length of time between its respective investment and the sale. Apportionment of this sort has been used in analogous cases. Thus, where a taxpayer purchased a lot in 1919, built a house on it in 1921, and sold both in 1922, it was held that the profit

46. First appearing in $\$ 206$ of the 1921 Revenue Act, 42 SIst. 232, this provision was also contained in the 1924, 1926, 1928, and 1932 Revenue Acts. See 26 U.S.C.A. $\S 101$ (1934) (historical note).

47. 4S Stat. 714 (1934), 26 U.S.C. $\$ 101$ (1934). For a discussion of the new provisions, see Hendricks, Capital Gains and Losses (1935) 49 HAnv. I. REv. 262.

48. If property has been held less than one year, $100 \%$ is tasable; one to two years, 80\% tarable; two to five years, $60 \%$ tarable; five to ten years, $40 \%$ tasmble; over ten years, 30\% taxable. 48 STAT. 714 (1934), 26 U.S.C. (1934) \$101(a).

49. W. H. Hay, 25 B.T. A. 96 (1932); of. Dahlinger v. Commissioner, 51 F. (2d) 662 (C. C. A. 3d, 1931).

50. M. Enest Greenebaum, Jr., 27 B.T. A. SS9 (1933); D. C. Bothwell, 27 B.T.A. 1351 (1933), aff'd, 77 F. (2d) 35 (C. C. A. 10th, 1935); John C. Shafier, 23 B.T.A. 1294 (1933). 
could be subdivided, part being treated as attributable to the land, which had been held over two years, and was therefore taxable as capital gain, and part attributable to the house and hence taxable as normal gain. ${ }^{\text {"1 }}$ The question as to whether this device of apportionment is to be used in cases involving the process of transfer has arisen chiefly in. regard to the acquisition and exercise of stock rights.

Frequently a corporation issues to its stockholders rights to purchase additional shares of stock at below the market price. Such rights are very much like stock dividends in that they embody a part of the stockholder's equity which has hitherto been represented by the original stock. Therefore in Wood v. Commissioner, ${ }^{52}$ when a taxpayer who had long owned stock in a corporation received stock rights in 1927, exercised them, and sold the new stock within two years, the circuit court of appeals held that there was a continuity of investment from the time of acquisition of the original stock until the sale of the new stock such that the part of the profit attributable to the original investment which had given rise to the rights should be treated as capital gain, ${ }^{53}$ whereas the profit attributable to the new investment required to exercise the rights should be treated as normal gain. ${ }^{54}$ However, in Commissioner v. Cummings, 5 where the taxpayer bought rights on the open market in 1925, exercised them in 1929, and then sold the resulting stock in the same year, no apportionment was permitted, the whole profit being attributed to the 1929 investment, and hence taxed as normal gain. Superficially, these two decisions seem irreconcilable, for if the court will go behind the moment of the exercise of the right in one case, it would seem

51. Dunigan v. Burnet, 66 F. (2d) 201 (App. D. C. 1933), aff'g 23 B.T. A. 418 (1931); I. T. 2469, VIII-I Cum. Bull. 158.

52. 75 F. (2d) 364 (C. C.A. 1st, 1935).

53. For another use of this concept of continuity of investment, see E. V. Securities Corporation, 28 B.T. A. 914 (1933).

54. The question of how the profits should be split up has not yet been settled. The method used in the Wood case seems erroneous, and was disapproved in the later case of Macy v. Helvering, 82 F. (2d) 183, 186 (C. C. A. 2d, 1936). However, in that case the problem of computation was not argued. The simplest method apparm ently is to split up the profit in the ratio of the cost of the rights and the cost of their exercise. The cost of the rights can be calculated by finding the percentage of the cost of the original stock which may properly be attributed to the rights. Sce Maggs, Computation of Income on Sale of Dividend Stock or Subscription Rights (1924) 13 Calrf. L. Rev. 13. Then if "cr" is the cost of the rights, and "cer" is the cost of their exercise, and $C$ is the total cost or "cr" plus "cer", and $P$ is the total profit, then the profit attributable to the rights is $\frac{c r}{C} X P$, and the profits attributable to their exercise is $\frac{c e r}{C} \times$. This method, although simple, discriminates somewhat against the taxpayer, for it apportions the profit in the ratio of the respective costs, yet probably a large part of the appreciation took place before the exercise of the rights, and is entirely attributable to the original cost. Yet any attempt to prevent this inequality would probably require an unduly complicated formula.

55. 77 F. (2d) 670 (C. C.A. 5th, 1935). 
proper to do so in the other. ${ }^{00}$ Yet the distinction is justifiable from the standpoint of policy. The period between the acquisition of such rights and their exercise is generally fairly short. Hence, where the original investment is the purchase of rights on the market, the interval between that investment and the one involved in exercising the rights is usually so short that apportionment would seldom save the taxpayer enough to warrant the trouble it would entail. But where the original investment is the purchase of stock, and the rights are issued considerably later, the interval between the original investment and that involved in exercising the rights may well be long enough to make apportionment of substantial value to the taxpayer. Furthermore, the threat of losing the benefit of the holding period prior to the acquisition of the rights would discourage stockholders from exercising them, and this would in turn seriously affect the common corporate practice of attracting new capital by issuing stock rights.

\section{Miscellaneous Taxies}

Hitherto options have been considered only with reference to their use as a preliminary stage in the process of transfer. However, option contracts can be used as devices to give the optionee control over the property subject to option, with only the incidental purpose of leading to a future transfer. Where an option is used for this purpose, the contract often leads to an unusual contractual relationship between the optionor and the optionee, raising varied and interesting tax problems, 57 a few of which will be suggested.

In Ohio, land is exempt from property taxation if it is both owned and used by a charitable organization. An individual owning some temporarily unoccupied land conveyed it to a charitable organization in return for an option to repurchase the land for $\$ 10$ at any time after one year. It was held that the charity's bare legal title combined with actual use was sufficient to satisfy the statutory exemption provision, and that the land was therefore not taxable.

56. After the Cummings case was decided, the Board of Tax Appeals refused to follow the Wood case. May Rogers, 32 B.T.A. 1176 (1935). However, in Mracy v. Helvering, 82 F. (2d) 183 (C.C.A. 2d, 1936), the second circuit had facts presented similar to the Wood case, and permitted apportionment, expressly stating that the Wood and Cummings case were not inconsistent.

57. For further problems involving options, see Rodriques v. Edwards, $40 \mathrm{~F}$. (2d) 408 (C. C. A. 2d, 1930) ; Estate of Erskine 25. Ross, 29 B. T. A. 227 (1933); Albert Russel Erskine, 26 B.T.A. 147 (1932); Helvering v. Salvage, 56 S. Ct. 375 (1936); Realty Sales Co., 10 B.T.A. 1217 (1928).

58. Zangerle v. State ez rel. Gallagher, 120 Ohio St. 139, 165 N.E. 709 (1929), (1929) 39 YaLE I. J. 137; cf. Mausoleum Builders of N. J. v. State Board of Tases \& Assessments, 90 N. J. Law 163, 100 Atl. 236 (1917); 1forris et al. v. Board of Commissioners of Love County, 74 Okla. 199, 177 Pac. 900 (1917). 
The Revenue Act provides that the income of a revocable trust is taxable to the settlor. A taxpayer, in order to lessen his income taxes, transferred to an irrevocable trust stock worth $\$ 200$ a share, taking in return, however, an option to repurchase any of the stock for $\$ 10$ a share. The Board of Tax Appeals held that the settlor here had a power of revocation as to $19 / 20$ of the trust, and hence was taxable for that percentage of the income accruing to the stock. 58

The Revenue Act exempts from taxation all income derived from a public utility and accruing to any political subdivision of a state. A city which desired to construct a reservoir, but had reached its debt limit, persuaded certain public spirited citizens to organize a public utility corporation to build the reservoir. This corporation issued $\$ 1,000,000$ of stock, but the corporate charter specifically provided that the stockholders were entitled to cumulative dividends at a rate limited to $7 \%$ a year, that the stock could be retired at any time at par, and that after two years, all profits beyond the dividends had to be used to retire outstanding stock. The corporation then agreed to supply the city with water in return for part of the city's water rents, and further gave the city the option at any time to purchase the reservoir in return for a sum equal to the par value of the stock still outstanding. The income of the corporation was held taxable as not accruing to the city within the meaning of the Act. ${ }^{00}$

\section{THE DECLARATORY JUDGMENT AND THE INSURANCE CONTRACT}

THE declaratory.judgment, ${ }^{I}$ a remedy singularly well adapted to controversies arising from the insurance contract, has been invoked with increasing frequency in insurance cases. ${ }^{2}$ While the insurer simply promises to pay an amount of money upon the happening of some contingency in the future, the continued expectation of the policyholder that the insurance

59. Charies T. Fisher, 28 B.T.A. 1164 (1933).

60. Decatur Water Supply Co., 34 B.T.A., April 9, 1936.

1. Declaratory judgment statutes have been enacted in 39 states and territories. See Borchard, Recent Developments in Declaratory Relief (1936) 10 TEMr. L. Q. 233, 245. A Federal Declaratory Judgments .Act was adopted in 1934. 48 SxAT. 955, 28 U.S. C. $\$ 400$ (1934).

2. The declaratory judgment has long been extensively used in insurance cases abroad. See foreign cases cited in Borcerard, Declaratory Judgnients (1934) 490497 , covering the subject of this comment.

The declaration has been resorted to successfully on a large scale in other fields as well, particularly in patent cases. (1935) 45 YALE I. J. 160; (1936) 45 Y ALE L. J. 1287. 
company intends to perform its obligation is as significant to him as ultimate recovery after loss. Nor is the insurer desirous of waiting for suit upon a policy for the adjudication of a controversy rooted in facts which had occurred many years previously. Hence any device is welcomed which will conclusively dispel uncertainty and insecurity in the generally long period during which insurance policies purport to be operative.

In the various situations which arise during the life of a policy law and equity have not failed entirely in furnishing remedies. In some instances damages, rescission, cancellation, reformation, restitution, interpleader, and the injunction have been employed; but in others even the most strenuous display of legal imagination could not make a conventional remedy available. The declaratory judgment furnishes a technique adequate to meet these difficulties, obviating much of the procedural hardship associated with suits or actions for older remedies, ${ }^{3}$ and providing a remedy for many situations for the first time: So long as the-conditions of justiciability are present-interested parties asserting adverse claims in a controversy ripe for judicial determination - the availability of other remedies should not of itself bar the granting of the declaration; for there is no reason to compel a plaintiff to demand a drastic, complicated, and expensive remedy, when a mild, simple, and inexpensive one, disposing of the issue without disturbing the relations of the parties, is adequate. ${ }^{\circ}$

A survey of the many situations in which declaratory relief has been invoked indicates the utility of this procedure in the field of insurance. The remedy has not been confined to any one class of litigant or to any recurring groove of situations; for insurer, insured, beneficiary, and other interested parties have employed it with effect to settle a variety of issues. A survey of these cases will also serve to illustrate how the declaratory judgment is being digested into the body of the law, and to what extent the declaratory judgment in action does or can simplify and reform procedure, as its proponents have urged. The declaratory judgment is a comparatively new remedy in this country and as yet is remarkably free from ambiguity and hocus-pocus. The attitude of the courts toward it will have direct consequences upon its development. Decisions on declaratory relief written in the spirit of "trial by combat" could soon weave an unfortunate crust of technicality around the declaratory judgment.

3. See, e.g., p. $2 S S$ infro where the availability of the equitable remedy of cancellation is discussed.

4. See, e.g., p. 293 infra where is discussed a situation under a disability policy in which neither law nor equity provides a remedy.

5. Borchard, Declaratory Judganents (1934) 29-50; Legis. (1936) 49 EnRrv. L. REv. 1351. It will be assumed in the situations described in the remainder of this comment that conflicting claims have been asserted by the parties out of court.

6. BORCEARD, op. cit. supra note 5, at 162 . Although reference will ba made throughout this comment to the availability of other remedies, it should not be inferred that declarations ought to be refused on that account. 
Validity of Policy. Both before and after loss there may be considerable doubt as to whether or not a policy is valid. An insurer may wish to have a policy voided on grounds of fraud or misrepresentation, and until an adjudication of that issue the insurer can determine neither its responsibility for the risk nor the necessity of maintaining reserves to offset the contingent liability. The equitable bill of cancellation might be available in such situations, but this relief is not always decreed since it is said after a loss has occurred that the insurer's privilege eventually to defend an action on the policy provides an adequate legal remedy precluding equitable juriscliction. Only when a loss has not yet occurred ${ }^{8}$ or when the policy contains an incontestable clause $e^{\mathfrak{B}}$ is that privilege regarded as inadequate. The beneficiary, however, may delay bringing suit on the policy not only to bring himself within the protection of an incontestability clause but also to make evidence less accessible to the insurer. ${ }^{10}$ Aware of these difficulties, several courts

7. Phoenix Mut. Life Ins. Co. v. Bailey, 13 Wall. 616 (U.S.1871); Di Giovanni v. Camden Fire Ins. Ass'n, 296 U.S. 64 (1935); Aetna Life Ins. Co. v. Richmond, 107 Conn. 117, 139 Atl. 702 (1927) ; cf. Globe Mut. Life Ins. Co. v. Reals, 79 N. Y. 202 (1879). Contra: Commercial Mut. Ins. Co. v. McLoon, 96 Mass. 351 (1867); Aetna Life Ins. Co. v. Bellos, 158 Tenn. 554, 13 S.W. (2d) 795 (1929), rehcaring denied, 158 Tenn. 562, 14 S.W. (2d) 961 (1929); see New York Life Ins. Co. v. Steinman, 103 N. J. Eq. 403, 404, 143 Atl. 529 (Ch. 1928).

And in one case where the legal remedy was clearly inadequate the court refused to decree cancellation. The insurer's defenses to the claim of the insured for disability payments were fraud in procuring the policy and non-disability. In an action for those payments a general verdict by a jury for the defendant insurer would not be res jitdicata on the question of fraud in subsequent proceedings brought by the insured against the insurance company for additional installments. Nichols v. Pacific Mut. Life Ins. Co., 84 F. (2d) 896 (C. C. A. 8th, 1936), cert. filed, (1936) 4 U. S. L. WeEk 222.

8. Before loss a company may generally maintain suit in equity to cancel a policy for fraud, concealment, or misrepresentation. Travelers Ins. Co. v. Evslin, 101 N. J. Eq. 527, 139 Atl. 520 (Ch. 1927). It is by no means clear, however, that equitable relief may be obtained on other grounds. Compare Connecticut Mut. Life Ins. Co. v. Home Ins. Co., 6 Fed. Cas. No. 3,107 (C. C. D. Conn. 1879) with Brooking v. Maudslay, Son \& Field, 38 Ch. D. 636 (1888) (after loss).

9. Brown v. Pacific Mut. Life Ins. Co., 62 F. (2d) 711 (C. C. A. 4th, 1933); New York Life Ins. Co. v. Steinman, 103 N. J. Eq. 403, 143 Att. 529 (Ch. 1928); Prudential Ins. Co. v. Ptohides, 186 Atl. 386 ( $\mathrm{Pa}$. 1936). Equitable relief will not be granted if insured has already brought suit on the policy or indicated that he will do so during the contestable period. Stewart v. American Life Ins. Co., (C. C.A. 10th,. 1936) 4 U. S. L. WeEK 80.

10. See Commercial Mut. Ins. Co. v. McLoon, 96 Mass. 351, 352 (1867) ; New York Life Ins. Co. v. Steinman, 103 N. J. Eq. 403, 404, 143 Atl. 529 (Ch. 1928). But see Brooking v. Maudslay, Son \& Field, $38 \mathrm{Ch}$. D. 636, 644 (1888). Bills to perpetuate testimony would probably be available to prevent loss of evidence, [Ocean Ins. Co. v. Bigler, 72 Me. 469 (1881)] but resort to that action would result in added expense and a multiplicity of suits. Moreover it is more desirable to present the testimony first hand to those who must determine the questions of fact than to submit it through depositions. See First-Trust Joint Stock Land Bank of Chicago v. Meredith, 60 P. (2d) 1023, 1025 (Cal. 1936). 
have granted declarations of invalidity after loss, 11 and in one case such a declaration was made before loss. ${ }^{12}$ A declaration at the behest of the insurer that the policy is void is clearly within the scope of the usual declaritory judgment statute, permitting the declaration, in appropriate circumstances, of "rights and other legal relations."13

On the other hand an insured, for most pressing practical reasons, ${ }^{11}$ will often wish to ascertain whether a policy is in force before any loss has occurred. He might also seek to have the policy declared void before loss in order to recover premiums paid, or, after loss, sue to determine whether the policy is valid before initiating costly litigation on other issues. In the first two cases equitable decrees validating ${ }^{10}$ or voiding ${ }^{10}$ the policy might be granted, while in the last a suit for damages would provide something of a remedy. Appreciating these procedural difficulties, some courts have, on behalf of the insured, granted declarations as to the validity of policies

11. In te Londion County Commercial Reinsurance Office [1922] $2 \mathrm{Ch} .67$; Royal London IIutual Ins. Soc. v. Barrett [192S] Ch. 411; Is te Arbitration Between Samson and Atlas Ins. Co., 28 N. Z. 1035 (1909); see Aetna Life Ins. Co. v. Richmond, 107 Conn. 117, 119, 139 Atl. 702 (1927). Contra: Brooling v. Maudslay, Son \& Field, 38 Ch. D. 636 (1888).

12. Cf. Honour v. Equitable Life Ass. Soc. [1900] $1 \mathrm{Ch}$. $\mathbf{5 5 2 .}$

13. Borchard, Decraratory Judgarents (1934) 74, 314 et seq. Numerous declasations have been made as to the petitioner's freedom from duty (privilege) and the defendant's no-right. Guaranty Trust Co. v. Hannay \& Co. [1915] 2 K. B. 536; Zenie Bros. v. Miskend, 10 F. Supp. 779 (S. D. N. Y. 1935).

14. E.g., to find out whether new insurance must be obtainet; or, if for any reason new insurance is unobtainable, to have the security of the existing policy determined.

15. Day v. Connecticut Gen. Life Ins. Co., 45 Conn. 480 (1S78); Indiana Iife Endowment Co. v. Carnithan, 62 Ind. App. 567, 109 N.E. S51 (1915); Cohen v. New York Mut. Life Ins. Co., 50 N. Y. 610 (1872); Mfeyer v. Knickerbocker Life Ins. Co., 73 N.Y. 516 (1S78); American Trust Co. v. Virginia Life Ins. Co., 173 N. C. 558, 92 S. E. 706 (1917); see Killian v. Afetropolitan Iife Ins. Co., 251 N. Y. 44, 4S! 166 N. E. 798, 800 (1929).

16. Green v. Security IIut. Life Ins. Co., 159 Mo. App. 277, 140 S. W. 325 (1911); Myyler v. Fidelity MIut. Life Ins. Co., 64 Okl. 293, $167 \mathrm{Pac} 601$ (1917); Equitable Life Ass. Soc v. Maverick, 7S S. W. 560 (Tex: Civ. App. 1904). Insured might also recover premiums paid by bringing an action for money had and received; setting up the invalidity of the policy. McCann v. Metropolitan Iife Ins. Co., 177 Mrss. 280, 58 N. E. 1026 (1901); American Life Ins. Co. v. MicAden, 109 Pa. 399, 1 Atl. 256 (1885).

17. Honetsky v. Russian Consol. MIut. Aid Soc, 114 N. J. L. 240, 176 Atl. 670 (Sup. Ct. 1935); Seligman v. Eagle Insurance Co. [1917] 1 Ch. 519; Life Ins. Co. of Australia v. Phillips, 36 C. I. R. 60 (1925); cf. Ifissouri Cattle Ioan Co. v. Great Southern Life Ins. Co., 330 Mío. 98S, 52 S. W. (2d) 1 (1932); see Killian v. Mfetropolitan Life Ins. Co., 251 N. Y. 44, 4S, 166 N.E. 798, 800 (1929). But cf. Honour v. Equitable Life Ass. Soc. [1900] $1 \mathrm{Ch}$. 852. The above cases include requests both for validating and voiding policies. 
both before ${ }^{17}$ and after loss. ${ }^{18}$ In one case where the insured had paid a premium to an absconding agent, the policy was held valid. ${ }^{10}$ In another a policy has been declared void where the insurer fraudulently represented to the plaintiff that he had an insurable interest in the life of the person insured. 20

Coverage. Even if a policy is valid, a dispute may arise as to whether a particular loss falls within its terms. Typical controversies are whether insured's death was accidental or, with respect to disability insurance, whether insured is disabled. In these situations the insurer is often confronted with problems similar to those arising where the validity of a policy is in question. Adequate reserves for contingent liabilities must be maintained; expensive litigation upon many issues may be necessary for the determination of a narrow one; and evidence may become unavailable if insured delays bringing suit. Since none of the traditional remedies are available to insurer, ${ }^{2 I}$ he must await the pleasure of the insured or beneficiary in initiating an action. Motivated primarily by the threat of loss of evidence, insurance companies have in several recent cases petitioned for declaratory relief. In one case under the Federal Declaratory Judgments Act an insurance company sought to disclaim liability, on an accident policy on the ground that death was not accidental. The court, while conceding that an actual controversy existed, refused to grant a declaration on the theory that the statutory provision for the declaration of "rights and other legal relations" could be invoked only when the rights involved were those of the petitioner. ${ }^{22}$ It is clear, however, that the act was couched in Hohfeldian terminology, so that "duties" and "no-rights" were intended to be as much the subject of declaration as their respective correlatives, "rights" and "privileges". ${ }^{23}$ Since, moreover, declarations as to petitioner's "duties" are not uncommon, ${ }^{24}$ it hardly seems likely that this error will be perpetuated, although another federal court, in a case where insurer had denied insured's disability and its own duty to pay benefits, has similarly misinterpreted the act. While refusing

18. Condogianis v. Guardian Ass. Co. [1921] 2 A.C. 125 (P. C.); Bradbury v. Iondon Guarantee \& Accident Co., 40 C. I. R. 127 (1927); Saunders v. Queensland Ins. Co., 45 C.L.R. 557 (1931).

19. Frasch v. London \& Lancashire Fire Ins. Co., 213 Cal, 219, 2 P. (2d) 147 (1931) (before loss).

20. Tofts v. Pearl Life Assurance Co. [1915] 1 K. B. 189 (C.A.).

21. See note 7 supra.

22. Columbian Nat. Life Ins. Co. v. Foulke, 13 F. Supp. 350 (W.D. Mo. 1936), criticized in Gully v. Interstate Natural Gas Co., 82 F. (2d) 145 (C. C. A. 5th, 1936). See also, Borchard, Recent Developments in Declaratory Relief (1936) 10 Texp. L. Q. $233,242$.

23. Hearings before Subcommittee of Sentate Connnittee on Judiciary on H. R. 5623, 70th Cong. 1st Sess. (1928) 43 (testimony of Professor Borchard); Borchard, The Federal Declaratory Judgments Act (1934) 21 VA. L. REv. 35, 45; Borchard, supra note 22 at 243; Legis. (1936) 49 HARv. L. REv. 1351, 1357 n. 41.

24. See note 13 stspra. 
to grant a declaration on the insurer's "duty to pay", that court did determine the issue of disability by granting a declaration as to the "right" of the insurer to premiums, if the policy is to be kept in force, a claim normally waived during disability. ${ }^{25}$ Repeated refusals by the federal courts to make declarations as to "duties" 20 would seriously restrict the utility of the declaratory judgment. An even greater error was committed by a circuit court of appeals which refused, in a similar case, to issue any declaration at all, asserting that there was no "actual controversy" between the parties, notwithstanding the apparent presence of all the elements of justiciability: ${ }^{27}$ These decisions cannot be justified on the ground that the insured's choice of forum is restricted by granting the insurer a declaration, since the insured has ample opportunity to choose his forum by initiating an action on the policy.

Although the insured is usually able to determine whether a loss is covered by bringing suit to recover on the policy, he frequently may be compelled to try a lengthy and expensive suit in order to determine this one issue. It is probably for this reason that declaratory judgments have been granted so often to an insured seeking to determine the liability of the insurer. ${ }^{23}$ But a desire to avoid expensive litigation is by no means the only resson for resort to declaratory relief in such cases. In some situations where an attempt is made to determine the liability of the insurer the insured may be either entirely without remedy or without a remedy immediately available. This is the situation under those indemnity policies where payment of the judgment by the insured is a condition precedent to the insurer's duty to indemnify. ${ }^{29}$ If the insured is unable to fulfill this condition precedent, the judgment will hang over his head as a çontinuing liability always collect-

25. New York Life Ins. Co. v. London, 15 F. Supp. 586 (D. MFass. 1936), (1936) 36 CoL. I. REv. 1168. A deciaratory judgment as to the insurer's right to premiums in policies substantially similar except that no benefits were presently payable was granted in Travelers Ins. Co. v. Helmer, 15 F. Supp. 355 (N. D. Gz. 1936).

26. Such declarations have been granted in insurance cases by other courts. See note 11 supra. But see Aetna Life Ins. Co. v. Bellos, $15 S$ Tenn. 554, 55S, 13 S.W. (2d) 795, 797 (1929), rehearing denied, 158 Tenn. 562, 14 S. W. (2d) 951 (1929).

27. Aetna Life Ins. Co. v. Haworth, 84 F. (2d) 695 (C. C. A. Sth, 1936), cort. granted, N. Y. Times, Nov. 17, 1936, p. 54, col. 4, (1936) 36 CoL. L. REv. 1163; but cf. Borchard, supra note 22 at 244.

2S. Farrell v. South East Iancashire Ins. Co. [1933] Ir. R. 36; University of New Zealand v. Standard Fire \& Marine Ins. Co. [1916] N.Z. 509; Tucker v. South British Ins. Co. [1916] N. Z. 1142 (whether disability clause covered inability to do "usual work" or "any work") ; Iichtenstein, Arnoldson \& Co. v. South British Ins. Co. [1918] N. Z. 353; Joyes v. National Ins. Co. of New Zealand [1932] N. Z. E02. Contra: NNesbitt v. Manufacturers' Casualty Ins. Co., $310 \mathrm{~Pa}$. 374, 165 Atl. 403 (1933).

29. Cases of this type will probably arise only infrequently in the future, since most indemnity policies now impose upon insurer a duty to defend and where such a duty is imposed the policy is usually held to be a policy of indemnity against liability for damages and not a mere contract of indemnity against damages. 3 falley $v$. American Indemnity Corp., $297 \mathrm{~Pa} .216,146$ Att. 571 (1929). For a discussion of cases arising over the "duty to defend" see p. 294 infra. 
ible if he comes into funds. A declaration of the insurer's duty ${ }^{30}$ may enable the insured to obtain a loan with which to perform the condition of paying off the judgment, and in this manner avoid the impairment of his credit. Also, where insured is threatened with suit, he may want to know whether, if liable, he is protected by the policy. ${ }^{32}$ Still another situation is that in which the policy provides for arbitration to determine the amount of loss; for if the type of loss is ultimately held not covered by the policy, the arbitration proceeding on the issue of the amount of loss is rendered useless. ${ }^{32}$ In most of these situations, relief by declaration, deemed peculiarly appropriate by the courts, has been readily granted. ${ }^{33}$

Disability Policies. When coverage is in issue under disability policies the remedy of neither insurer nor insured is entirely satisfactory. When an insurance company denies disability and refuses to make the payments alleged to be due, the insured is limited in his recovery to those installments which have accrued, and is able to recover subsequent installments only by bringing suit after a default. ${ }^{34}$ A decree for specific performance would probably not be granted since the legal remedy would be regarded as adequate. ${ }^{35}$ Even where anticipatory breach of such contracts is recognized, a right to immediate damages is not a satisfactory remedy, because of the uncertainty as to the length of disability. The original purpose of the policy would be better served by a judgment for accrued installments coupled with a declaration of the insured's right to future installments, with the privilege reserved to the insurance company of re-opening that judgment when it maintains the disability has ended. While this procedure shifts the burden of proof of disability to the insurer, it does not seem inequitable, since the insured has already made a showing of actual disability and since the policy contemplated uninterrupted payments during disability..$^{30}$ Despite the obvious advantages of declaratory relief, two American courts have refused declara-

30. Cf. cases cited note 51 infra. But cf. Piper v. Spence [1925] I D. L. R. (Manit.) 334.

31. Cf. Dobson v. Ocean Accident \& Guarantee Corp., 124 Neb. 652, 247 N. W. 789 (1933); but cf. Piper v. Spence [1925] 1 D. L. R. (Manit.) 334. See, also, discussion of "duty to defend", p. 294 infra.

32. A declaration as to validity has been granted before arbitration was begun. Western Australian Ins. Co. v. Dayton, 35 C. L. R. 355 (1924). Cases granting declarations as to whether such arbitration is a condition precedent to recovery are cited in note 51 infra.

33. See cases cited notes 30,31 and 32 supra.

34. New York Life Ins. Co. v. Viglas, 297 U. S. 672 (1936), (1936) 46 YALE L. J. 181; Puckett v. National Annuity Ass'n, 134 Mo. App. 501, 114 S. W. 1039 (1908); notes (1932) 81 A.I.R. 379, (1935) 99 A.L.R. 1171. Contra: Federal Life Ins. Co. v. Rascoe, 12 F. (2d) 693 (C. C. A. 6th, 1926), cert. denied, 273 U. S. 722 (1926).

35. Cf. Brown v. Pacific Mut. Life Ins. Co., 62 F. (2d) 711 (C. C. A. 4th, 1933). But see note 41 infra.

36. (1936) 46 Yale L. J. 181, 184. But of. Mid-Continent Life Ins. Co. v. Walker, 128 Okla. 75, 260 Pac. 1109 (1926). 
tions in such cases, one court basing its decision on the flimsy ground that since it did not recognize any recovery for future installments, declaratory relief would not be granted, ${ }^{37}$ the second mistakenly assuming that an action for a declaration could be brought only where no other remedy was available. $^{38}$ Such declarations ${ }^{39}$ and similar ones, ${ }^{30}$ however, have been approved and continuing judgments of this form, while not termed declaratory, have been granted in several jurisdictions. ${ }^{41}$

In at least one situation under a disability policy the insurance company is without an adequate remedy at law or equity. A disability policy is usually an extra feature appended to a life insurance policy and the insurance company normaily agrees, in addition to making disability payments, to waive premiums during the period of disability. The insured, claiming disability, may neglect to pay premiums and at the same time assert that the policy is in full force. He may refrain from bringing suit or even threatening to bring suit for the disability payments. Under these facts the issue of disability will not be decided until many years later when suit is brought on the life insurance policy and when the facts of the alleged disability may vell have become lost, blurred, and distorted by the passage of time. While a declaration as to the duty of the insurer to make disability payments has been refused in such cases, the issue of disability has been determined for the purpose of declaring the "right" of the insurer to premiums."2

37. . Brix v. Peoples Miutual Life Ins. Co., 2 Cal. (2d) 446, 41 P. (2d) 537 (1935), rev'g 29 P. (2d) 233 (1934).

38. Green v. Inter-Ocean Casualty Co., 203 N. C. 767, 167 S. E. $3 S$ (1932).

39. Bullas v. Empire Life Ins. Co. [1931] 4 D. I. R. (Ont.) 443 (denied on merits) ; Brix v. People's Mutual Life Ins. Co., 29 P. (2d) 233 (1934), rev'd, 2 Cal. (2d) 446, 41 P. (2d) 537 (1935); see Killian v. Metropolitan Iife Ins. Co., $251 \mathrm{~N}$. Y. $44,48,166$ N.E. 798,800 (1929).

40. Borchard, Declaratory Judgrents (1934) 371-376; cf. United States v. Dismuke, 76 F. (2d) 715 (C. C. A. 5th, 1935), af'd, 297 U. S. 167 (1936), relicaring denied, 297 U. S. 728 (1936); (1927) 27 CoL. L. Rev. 332.

41. Equitable Life Ass. Soc. v. Branham, $250 \mathrm{Ky} .472,63 \mathrm{~S}$. W. (2d) 498 (1933); Equitable Life Ass. Soc. v. Goble, $254 \mathrm{Ky} .614,72 \mathrm{~S}$. W. (2d) 35 (1934); Mfelancon v. Provident Life \& Acc. Ins. Co., 176 La. 1055, 147 So. 346 (1933) ; cf. John Hancocls Afut. Life Ins. Co. v. Large, $230 \mathrm{Ala} .621,162$ So. 277 (1935); Waterstrow v. National Americans, 183 Ill. App. S2 (1913) ; Colburn v. Clover Leaf Casualty Co. 206 Ill. App. 327 (1917) ; Southern Travelers' Ass'n v. Boyd, 1 S. W. (2d) 446 (Tes: Civ. App. 1927), modified, 12 S.W. (2d) 183 (Tex. Comm. App. 1929). Contra: Brotherhood of Locomotive Fire. \& Eng. v. Simmons, 190 Ark. 480, 79 S. W. (2d) 419 (1935); New York Life Ins. Co. v. English, 96 Tex. 268, 72 S. W. 58 (1903); State Life Ins. Co. v. Atkins, 9 S. W. (2d) 290 (Tex. Civ. App. 1928); cf. Mfid-Continent Life Ins. Co. v. Walker, $12 S$ Okla. 75, $260 \mathrm{Pac} 1109$ (1926). Continuing judgments have become customary in Kentucky. See note (1935) 99 A.I. R. 1171, 1177.

42. See note 25 sipra. In determining whether to award declaratory judgments in such cases the recent losses, in some measure due to "falsed" claims, suffered by insurance companies under disability policies, should be considered. See Aclerman, Anticipatory Repudiation and Disability Insurance (1936) 1 U. of NEwars I REv. 47,48 n. 14. 
Duty to defend. Ascertaining whether a loss is within the coverage of a policy becomes particularly important in indemnity policies, typically accident liability policies, which usually impose upon the insurer a duty to defend all actions covered by the policy. In the absence of such a determination both parties are left between the horns of a dilemma. If it defends, the insurance company may try an expensive negligence case in which a court may later hold it is under no duty to pay. By refusing to defend, the company loses all opportunity to dispute the injured party's right to recovery. The insured has a similar unhappy choice of alternatives. The law offers no method, other than the declaratory judgment, of deciding this narrow issue expeditiously and alone. Recognizing this fact, several courts have granted declaratory relief to both insurer ${ }^{43}$ and insured. ${ }^{44}$ The difficulty of securing the declaration before the damage suit is brought to trial might be overcome by a rule of court giving preference to declarations in such cases. ${ }^{45}$

Rights and privileges of insured. A dispute may arise as to the rights and privileges of the insured other than his right to recovery on the policy. While after loss a suit on the policy may be of some utility, before a loss occurs there is no available method of determining such questions other than a suit for a declaration of rights. Before loss the privilege of the insured to set off the paid up value of his policy against his debt to the company, then in liquidation $;{ }^{46}$ the privilege of a trustee of a missing person to avail himself of certain options provided for in the policy when the premiums were not paid $;^{47}$ and the right of plaintiff, seeking to be adjudged owner of a policy on the life of his assignor, to the loan value of the policy, ${ }^{48}$ have been made the subject of declarations sought against insurance companies. Similarly, declarations requested after loss have put in issue the right to be paid in cer-

43. Ohio Casualty Ins. Co. v. Plummer, 13 F. Supp. 169 (S.D. Tex. 1935); Commercial Casualty Ins. Co. v. Humphrey, 13 F. Supp. 174 (S. D. Tex. 1935); American Motorists Ins. Co. v. Central Garage, 86 N. H. 362, 169 Atl. 121 (1933); Merchants Mut. Casualty Co. v. Pinnard, 183 Atl. 36 (N.H. 1936) ; Utica Mut. Ins. Co. v. Glennie;, 132 Misc. 899, 230 N. Y. Supp. 673 (Sup. Ct. 1928); Merchants Mut. Casualty Co. v. Ieone (Sup. Ct. Mass. Suff. County, 1936); Sun Indemnity Co. v. Triangle Furniture Co. (Sup. Ct. N. Y. Spec. Term Part III), opinion by Valente, J., in Record, p. 6, aff'd withont opinion, 289 N. Y. Supp. 821 (App. Div. 1st Dep't 1936); cf. American Motorists Ins. Co. v. Kopka, 186 Atl. 335 (N. H. 1936). But cf. United States Fidelity \& Guaranty Co. v. Savoy Grill, 51 Ohio App. 504, 1 N. E. (2d) 946 (1936):

44. Cf. Updike Inv. Co. v. Employers Liability Ass. Corp., 128 Neb. 295, 258 N. W. 470 (1935). But cf. Piper v. Spence [1925] 1 D. L. R. (Manit.) 334.

45. Several states make statutory provision for early hearing of declarations. See, e.g., Ky. Codes ANN. (Carroll 1932) Civ. Prac. \$639a-3; Mircr. Coxrr. Laws (1929) § 13904.

46. Paddy v. Clutton [1920] 2 Ch. 554.

47. Day v. Metropolitan Life Ins. Co., 11 Cal. App. (2d) 681, 54 P. (2d) 502 (1936).

48. Morrison v. New York Life Ins. Co., N. Y. L. J. April 17, 1936, p. 1956, col. 1 (Sup. Ct. Spec. Term Part III). 
tain currency ${ }^{49}$ and the right to the full-proceeds of the policy where the insurance company sought to apply a part to a mortgage debt for which the policy was collateral security, ${ }^{50}$ and also have determined whether furnishing rebuilding plans and leaving debris on the land pending arbitration were conditions precedent to recovery upon a fire insurance policy. ${ }^{\text {th }}$

Change in by-laws. Similarly the rights and privileges of an insurance company are often uncertain, particularly when important changes in general policy are contemplated. A fraternal association may find it necessary to revise its by-laws, increase assessments, reduce benefits, or adopt some other course of action of doubtful validity under its by-laws or a state statute. Before making the modifications the insurer would like to have their validity determined against a contesting superintendent of insurance or policyholder, rather than risk having far-reaching changes upset after they have been effected. On the other hand, the insured may wish to challenge the legitimacy of the revisions. The declaration provides a method for resolving such controversies simply ${ }^{52}$ and has been resorted to frequently.53 One warning,

49. Anderson v. Equitable Life Ass. Soc., 42 T. I. R. 123 (K B. 1925) ; cf. Plummer Hat Co. v. British Traders Ins. Co. [1932] N. Z. 576 (measure of loss of profits).

50. Douglas v. Mrutual Life Ass. Co., 13 Alberta L. R. 18 (1918).

51. Young v. New Zealand Ins. Co., 29 N. Z. 50 (1909); United Ins. Co. v. Arthur [1929] N. Z. 33 (whether arbitration as to amount of loss is condition precedent); $c f$. Webb v. Queensland Ins. Co. [1920] N. Z. 118 (occurrence of conditions precedent). Declarations have also been granted as to whether in policies of indemnity p3yment of the judgment is a condition precedent to recovery. Malley v. American Indermity Corp., 297 Pa. 216, 146 Atl. 571 (1929); In re Law Guarantee Trust \& Acc. Soc [1914] 2 Ch. D. 617 (C. A.) ; cf. Post v. Mfetropolitan Casualty Ins. Co., 227 App. Div. 156, 237 N. Y. Supp. 64 (4th Dep't 1929), aff'd, 254 N. Y. 541, 173 N. E. 857 (1930). Insured might be able to raise the same issue by suing the insurer after judgment for the amount of the loss. See Malley v. American Indemnity Corp., sibra at 223, 146 Atl. at 573.

52. Insured may challenge the validity of the changes by seelsing to enjoin their enforcement. Cf. Boyer v. Travelers' Protective Ass'n, 75 F. (2d) 440 (C. C. A. 3d, 1934). Insurer, however, can not initiate any proceeding other than the declaration to determine the validity of the modifications.

53. By-law changes: United Order of Foresters v. Afiller, $178 \mathrm{Wis.} 299,190 \mathrm{~N}$. W. 197 (1922) ; cf. St. John's Baptist Soc v. Ukranian Nat. Ass'n, 105 N. J. Eq. 69, 146 Atl. 886 (Ch. 1929) ; Buffalo Ass'n of Fire Underivriters v. Trosicel-Dimicl: Co., 141 Misc. 333, 253 N. Y. Supp. 40 (1931). Reduced Benefits: Grainger v. Order of Canadian Home Circles, 31 Ont. L. R. 461 (1914), aff'd, 33 Ont. I. R. 116 (1915); of. Thiseiton v. Commercial Union Ass. Co. [1926] Ch. SSS (increase in interest rates); Honetsly v. Russian Consol. Mut. Aid Soc, 114 N. J. L. 240, 176 Atl. 670 (1935). Inercascd Assessments: Quinn v. Kenton \& Campbell Benevolent Burial Ass'n, 221 Ky: 750, 259 S. W. 989 (1927) ; Supreme Tent of Knights of Mfaccabees v. Dupriest, 235 Ky. 46, 29 S. W. (2d) 599 (1930); cf. Snowden v. Miasonic Life Ass'n of West. N. Y., $244 \mathrm{Ky}$. 286, $50 \mathrm{~S}$. W. (2d) 569 (1932). Reductions in benefits and increases in assessments are of course usually effected through changes in by-laws.

Similar matters, dealing with important questions of general policy have been put in issue by declarations, asked usually against administrative officers. Kenton \& Campball Benev. Burial Ass'n v. Quinn, 244 Ky. 260, 50 S. W. (2d) 554 (1932) (validity of 
however, should be made. Care should be taken that all persons having a substantial interest in the controversy be made parties at least by representation, since the courts will refuse to grant a declaration where it feels that there has not been an adequate representation of opposing interests. ${ }^{\text {.4 }}$

Determining Beneficiary. Questions may arise concerning the rights of parties other than the insured against the insurer. The typical situation is that where there are several claimants to the proceeds of a policy. When suit is brought against an insurer who admits liability but is uncertain as to who is entitled to the proceeds, he can usually invoke the equitable remedy of interpleader. While interpleader is adequate for many situations, particularly since the enactment of the Federal Interpleader Act of 1936, ${ }^{\text {, }}$ in some cases it is circumscribed by technical restrictions. ${ }^{\text {B }}$ Furthermore it may be invoked only by the insurer and in this respect is a less supple and direct remedy than the declaratory judgment, which is available both to insurer and to claimants. Declarations have been granted to resolve conflicts between vendor and purchaser, ${ }^{57}$ executor and assignee, ${ }^{58}$ option-holder-lessee and owner, ${ }^{59}$ rival beneficiaries under a surety bond, ${ }^{00}$ and others. ${ }^{01} \mathrm{~A}$ dec-

statute); Bank Sav. Life Ins. Co. v. Baker, 120 Kans. 756, 244 Pac. 862 (1926) (construction of statute); Australian Mut. Provident Soc. v. Attorney-General [1916] N. 2. 179 (validity of proposed insurance policy); New York Life Ins. Co. v. Public Trustee [1924] $2 \mathrm{Ch} .101$ (confiscability of policies as enemy property); cf. General Ins. Co. v. Ham, 57 P. (2d) 671 (Wyo. 1936).

In a recent case a declaration seeking to compel the superintendent of insurance and a rating bureau to approve a form of policy plaintiff desired to take out was refused. Riebs Co. v. Mortensen, 219 Wis. 393, 263 N. W. 169 (1935).

54. Continental Mut. Ins. Co. v. Cochrane, 89 Colo. 462, 4 P. (2d) 308 (1931) (duty to keep intact charter membership fees; policyholders not joined). But $c f$. Northwestern Nat. Ins. Co. v. Freedy, 201 Wis. 51, 227 N. W. 952 (1929) (right of company to organize a casualty insurance company; policyholders not joined); National Reserve Life Ins. Co. v. Moore, 114 Kans. 456, 219 Pac. 261 (1923) (use of reserve fund for building purposes; company president only defendant).

55. Pub. L. No. 422, 74th Cong. 2d Sess. (1936), 28 U. S.C.A. $\$ 41$ (26) (Supp. 1936).

56. See Chafee, Modernizing Interpleader (1921) 30 YALE L. J. 814; BorCHARd, Declaratory Jungarents (1934) 72; New Amsterdam Casualty Co. v. Hyde, 148 Ore. 229, 242, 34 P. (2d) 930, 934 (1934), rehearing denied, 148 Ore. 229, 35 P. (2d) 980 (1934).

57. Brownell v. Board of Ed. of Saratoga Springs, 239 N. Y. 369,146 N. E. 630 (1925); Scott v. Crinnian, 43 Ont. L. R. 430 (1918).

58. Royal Exchange Ass. v. Hope [1928] Ch. 179 (C. A.).

59. Schnee v. Elston, 299 Pa. 100, 149 Atl.. 108 (1930).

60. New Amsterdam Casualty Co. v. Hyde, 148 Ore. 229, 34 P. (2d) 930 (1934) rehearing denied, 148 Ore. 229, 35 P. (2d) 980 (1934); cf. Mason's Adm'r v. Mason's Guardian, 239 Ky. 208, 39 S. W. (2d) 211 (1931).

61. Royal Ins. Co. v. Mylius, 38 C. L. R. 477 (1926) (owner and protected mortgagee); London \& Lancashire Ins. Co. v. Fisher [1924] N.Z. 1286 (personal representatives and receiver); cf. Ex Parte Hirsch's Committee, $245 \mathrm{KY} .132,53 \mathrm{~S}$. W. (2d) 211 (1932) (committee for insane insured and corporate beneficiary). 
laration as to who was the beneficiary of a policy was granted to the insured even before loss so that he might more wisely decide whether or not to discontinue payment of premiums.

Sharing liability. Analogous to the beneficiary cases are those where the dispute concerns the proportionate liability of several insurers of the same loss. If recovery is granted against one insurance company, it may generally bring an action for contribution against another insurer. ${ }^{\mathfrak{B}}$. Where the insurer has a right to contribution, it has been permitted to assert that right in an action for declaratory relief, ${ }^{64}$ either before or after judgment is entered against it. The insured, similarly, may seek a declaration as to the respective liability of several insurers. And while ordinarily an action at law against each insurer would lie, the liability of one defendant sometimes depends upon the determination of the liability of others. At least one court, recognizing when liability is so interwoven that the matter may be disposed of in an orderly fashion only in one proceeding, has granted a declaration.5

Insolvent insured. A situation where a third person is vitally interested in his rights against an insurer arises when an injured party finds that the prospective defendant who is protected by insurance is insolvent. ${ }^{C O}$ The insurance company may claim that the particular loss is not covered by the policy. Before trying an expensive negligence action against the insured, the injured party would of course like to determine whether the insurance company will be liable to the insured, for he seeks no Pyrrhic victory. A declaration of insurer's liability prior to the trial of the negligence action would appear an ideal remedy. Unless a statutory right of recovery is given the injured party against the insurance company, ${ }^{07}$ there may be some question as to whether the plaintiff's interest in the policy is sufficient to support his request for a declaration. The plaintiff's right to raise this issue is supported by the result in situations where the insured seeks a declaration against the insurance company without making the claimant a party; there the court refused the declaration on the ground that the claimant's interest was substantial enough to make him a necessary party. ${ }^{.5}$ And in one case where the

62. Cousins v. Sun Life Ass. Soc. [1933] Ch. 126 (C. A.).

63. Barnes v. Cushing, 168 N. Y. 542, 61 N.E. 902 (1901); Meigs v. Insurance Co. of North America, $205 \mathrm{~Pa}$. 37S, 54 Atl. 1053 (1903); Vasice, Irssuraisce (2d ed. 1930) 78, 762. As to contribution in indemnity insurance when there are two different policyholders see (1935) 45 YaLE I. J. 151.

64. Fidelity \& Casualty Co. v. American Surety Co., 313 Pa. 145, 169 Atl. 226 (1933); cf. Johnson v. Mortenson, 110 Conn. 221, 147 Atl. 705 (1929). But of. Schmidt v. IaSalle Fire Ins. Co., 209 Wis. 576, 245 N. W. 702. (1932).

65. Lawrence v. American Surety Co., 263 Ifich. 586, 249 N. W. 3 (1933), rehearing denied, 264 Mich. 516, 250 N. W. 295 (1933).

66. While this section is phrased in terms of situations arising under accident liability policies, the remarks made are equally applicable to other types of indemnity policies.

67. See, e.g., R. I. Gen. LAws (1923) \$1266.

68. Dobson v. Ocean Accident \& Guarantee Corp., 124 Neb. 652, 247 N. W. 789 (1933) ; Updike Inv. Co. v. Employers Liability Ass. Corp., 128 Neb. 295, 255 N. W. 470 (1935). 
insured and claimant joined in seeking a declaration as to the liability of the insurance company, the remedy was held to be available. ${ }^{60}$

Surety Bonds. Complicated disputes involving numerous parties arising from surety bonds provide a particularly appropriate setting for the application of declaratory relief. The case of $A$. E. Joy Co. v. New Amsterdan Casualty $\mathrm{Co}^{70}$ furnishes an example in point. A subcontractor's bond provided that the contractor should be refunded money expended by reason of the subcontractor's default. After such a default, two creditors of the subcontractor filed liens, and the owner refused to pay the general contractor until the liens were satisfied. The contractor then sought a declaration against the lienors, the subcontractor, the subcontractor's surety, and the owner to determine the relations of the parties and the validity of the liens, and the disputes were settled with a minimum of friction.

Conclision. The recently increased case experience of the declaratory judgment in the United States is rapidly giving the device a juristic content of its own, different both from the anticipatory definitions of its proponents and from its character in English and Dominion law. As one can see in the insurance cases, limitations which will restrict its availability to cases satisfying certain structural criteria are slowly taking shape. While it is still too soon in the history of declaratory relief to reduce such limitations to formula, they seem to be concerned mainly with two problems: how far need a controversy proceed toward conflict between the parties before it is proper for courts to grant declaratory relief? And of what importance is it in deciding on the availability of a declaratory judgment that other remedies are available in the particular case?

The cases which discuss the first question invoke the flexible formula that the defendant must be acting in such a way as to affect prejudicially the rights of the plaintiff. In applying this rule a tendency is discernible to refuse to issue declarations in cases other than those of the kind traditionally decided, despite the fact that the parties have asserted opposing claims in good faith out of court. ${ }^{71}$ This trend is by no means universal, however, for many courts regard the unfamiliarity of the situation and the consequent inability of the plaintiff to avail himself of other remedies as making the declaration ideally applicable. ${ }^{72}$

69. Post v. Metropolitan Casualty Ins. Co., 227 App. Div. 156, 237 N. Y. Supp. 64 (4th Dep't 1929), aff'd 254 N. Y. 541, 173 N. E. 857 (1930). But cf. Nesbitt v. MIanufacturers' Casualty Ins. Co., $310 \mathrm{~Pa}$. 374, 165 Atl. 403 (1933).

70. 98 Conn. 794, 120 Atl. 684 (1923). Other interesting surety cases where declarations were requested are: H. Michaelyan, Inc. v. New Jersey Fidelity \& Plate Glass Ins. Co., 229 App. Div. 123, 241 N. Y. Supp. 142 (1st Dep't 1930) · (validity of guarantee of purchaser's note, declaration granted vendor); Hall v. United States Nat. Bank of Omaha, 128 Neb. 254, 258 N. W. 403 (1935) (declaration denied, necessary parties not joined).

71. See Aetna Life Ins. Co. v. Haworth, 84 F. (2d) 695 (C. C. A. 8th, 1936), cert. granted, N. Y. Times, Nov. 17, 1936, p. 54, col. 4.

72. See e.g., Travelers Ins. Co. v. Helmer, 15 F. Supp. 355 (N. D. Ga. 1936). 